two lateral, rosette-like groups of spines; abdominal spines directed posteriorly; all spines bearing long hairs; entire dorsal surface bears smaller spines inter. mixed with those mentioned above.

Adult.-Mycotretus pulchra. This was described by Say in 1826 (Jour. Phil. Acad. Nat. Sci. V, 301; ibid. II, 345) under the generic name Tritoma. It is about 3 to $3.5 \mathrm{~mm}$., long, ovate, with the head, thorax and scutellum black, the elytra red with the apical third obliquely black, the black extending forward on the sides almost to the humeri. The head and thorax are finely and sparsely punctured, the punctures of elytral striæ are fine, the intervals finely punctate.

Smith ${ }^{2}$ records it from Hudson County and Woodside, N.J., with the statement that it was once common. Blatchley ${ }^{3}$ states that it is frequent in Marion, Vigo, Knox and Posey Counties, Indiana, April 9-June 19, and in Chagnon's Coleoptera of Quebec ${ }^{4}$ it is listed from Rouville Co., June, Montreal Isl., June and Laval Co., August.

\title{
A NEW GENUS AND SPECIES OF APHID FROM JAPAN. (HEM.)
}

BY RYOICHI TAKAHASHI,

Forest Experiment Station, Meguro, Tokyo, Japan.

This interesting aphid, which is found in the leaves of Podocarpus macrophylla, is rather inactive in habit. Both winged and wingless forms appear in May and later, in the second and subsequent generations. The sexuparæ are wingless, but most interesting is the fact that the oviparous female, as well as the male, is winged, these forms appearing during the month of September. As is common for species belonging to the Siphonophorina, wingless viviparous females may give birth to both winged and wingless progeny, but winged females produce only wingless forms.

\section{Neophyllaphis, new genus.}

This genus is closely related to Phyllaphis Koch, but differs from it as follows:

1. Sensoria on the third segment very peculiar in shape, being transversely narrow.

2. Body of the wingless form covered with white secretions which are not thready.

3 . The oviparous female is winged.

Winged female.-Body rather narrow and without hairs. Frontal tubercles absent. Antennæ nearly as long as body, six-segmented, spur of last segment very small, sensoria on third segment transversely narrow (ring-like in the oviparous female). Ocelli prominent. Abdomen without tubercles. Wings hyaline, the third oblique twice branched. Cornicles very small and much wider than long. Cauda not globular, but is constricted at base and slightly so at middle. Anal plate slightly sinuate. Empodial hairs absent.

Wingless female.-Similar to the winged female. Body with a white pulverulence. Eyes very small. Third antennal segment without sensoria.

Type.-Neophyllaphis podocarpi, n. sp.

2. Insects of New Jersey (N. J. St. Mus. Rept. 1909).

3. Coleoptera of Indiana, p. 546.

4. Prelim. List Ins. Prov. Quebec, Coleop. (1917, Suppl. Rept. Quebec Soc. Protec. 


\section{Neophyllaphis podocarpi, n. sp.}

Winged viviparous females.-Body rather narrow and without hairs. Frontal tubercles inconspicuous. Beak slender and reaching beyond the hind coxæ. Eyes large, ocelli prominent. Antennæ slender, without hairs, two

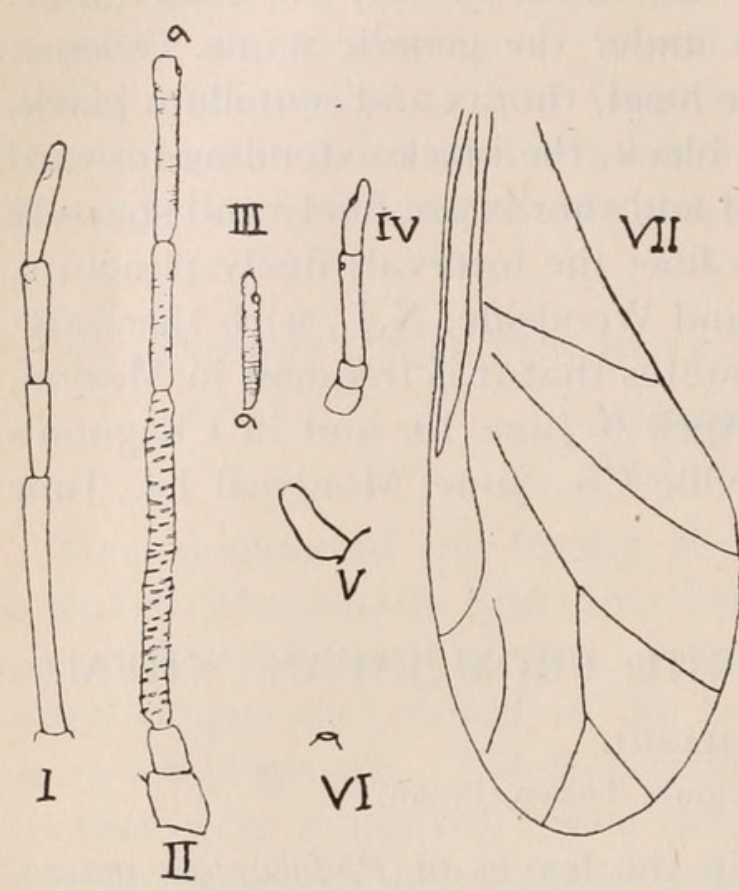

Fig. 6. Neophyllaphis podocarpi n. sp. I, antenna of wingless viviparous female; II-III, antenna of winged viviparous female; IV, antenna of immature form; V, lateral view of cauda of viviparous female; VI, cornicle of viviparous female; VII, wing of viviparous female.

brownish red, and legs pale brown. basal segments very short, the third nearly as long as the fourth and fifth combined and bearing about 60 small, transversely narrowed sensoria scattered over the entire length, the fourth slightly shorter than the fifth and without sensoria, sensoria at the distal end of the fifth segment small and circular, the sixth as long as the fourth with a small, round sensorium near the apex, spur of last segment very short. Wings not narrow, the third oblique vein twice branched. Abdomen without tubercles. Cornicles very small, much broader than long and broadest at base. Cauda large, rounded at apex, constricted at base and lightly so at middle. Anal plate sinuate. Legs moderately long, slender, and with a few short, fine hairs. Empodial hairs absent.

Colour dark reddish purple, eyes Wings hyaline with brown veins.

Length of body $1.3 \mathrm{~mm}$.; of antenna $1.1 \mathrm{~mm}$.; of fore wing $1.7 \mathrm{~mm}$.

Wingless viviparous female.-Body narrow, being broadest at middle, slightly pulverulent, and hairs absent. Frontal tubercles absent. Eyes very small. Beak slender and reaching beyond hind coxæ. Antennæ not reaching to tip of body, slender, and without hairs, third segment longer than the fourth and fifth combined, the fourth shorter than fifth, and the fifth subequal in length to the sixth, spur very short, sensoria absent excepting a single round one near apex of the fifth segment. Body without tubercles. Cornicles, cauda and legs as in the winged female.

Colour dark reddish purple, eyes black, antennæ and legs pale brown, cornicles black and cauda pale black.

Length of body $1.5 \mathrm{~mm}$; of antennæ $0.9 \mathrm{~mm}$.

Winged male.-Third antennal segment bearing numerous transverse sensoria which are irregularly scattered over the entire segment; fourth, fifth and sixth segments with fewer similar sensoria.

Winged oviparous female.-Third antennal segment with numerous long, encircling transverse sensoria regularly placed; none on remaining segments except the usual distal ones on the fifth and sixth segments. Hind tibia swollen and bearing numbers of sensoria on basal half.

Type Locality.-Meguro, Tokyo, Japan.

As in Neophyllaphis podocarpi the oviparous females of Greenidea kuwance Perg., Trichosiphum tenuicorpus Okag., and Cervaphis quercus Tak., are winged. 


\section{$2 \mathrm{BHL}$ Biodiversity Heritage Library}

Takahashi, Ryoichi. 1920. "A new genus and species of Aphid from Japan (Hem.)." The Canadian entomologist 52, 19-20.

https://doi.org/10.4039/Ent5219-1.

View This Item Online: https://www.biodiversitylibrary.org/item/22190

DOI: https://doi.org/10.4039/Ent5219-1

Permalink: https://www.biodiversitylibrary.org/partpdf/17018

\section{Holding Institution}

MBLWHOI Library

Sponsored by

MBLWHOI Library

\section{Copyright \& Reuse}

Copyright Status: NOT_IN_COPYRIGHT

This document was created from content at the Biodiversity Heritage Library, the world's largest open access digital library for biodiversity literature and archives. Visit BHL at https://www.biodiversitylibrary.org. 